\title{
THE EXISTENCE OF EXPECTATION GAP BETWEEN FINANCIAL STATEMENT USERS AND AUDITORS FROM VARIOUS ASPECTS IN SURABAYA
}

\author{
Pitaloka Devinta Ajeng \\ Department of Accounting, Faculty of Economics and Business, \\ University of Airlangga, Indonesia \\ E-mail: devintaajeng@gmail.com
}

\begin{abstract}
This research will discuss about the problems of expectation gap, including expectation gap on the issue of the auditor and the audit process, and the expectation gap on the issue of the role of auditors. Expectation gap is the difference in expectation between what people and users of financial reports from the auditors with what auditors believe to be their responsibility. This research aimed to examine whether or not there's a significant difference in perceptions between financial report users and auditors regarding the expectation gap on the issues of auditors and audit process, and some role which is included as an auditor's role or not. This research uses purposive sampling; the samples were financial report users (corporate accountant, investment analysts, banker, and tax people) and auditors which conduct practices as public accountants located in Surabaya. The questionnaire used in this research to collect data, and data is analyzed by using ANOVA one way test. In line with these objectives formulated hypothesis is that there are different perceptions about the expectation gap on the issue of the auditor and the audit process and the role of auditors. The results of this research show that there are differences in perceptions between financial report users (corporate accountant, investment analysts, banker, and tax people) and auditors regarding the expectation gap on the issues of auditors and audit process, auditor's role. Based on these results it is proposed that suggestions such as the expanded scope of the study area, samples and other issues such as the expectation gap independence, competence, or performance attributes.
\end{abstract}

\section{KEY WORDS}

Expectation gap, perception, auditors, audit process, auditor's role.

The demand of a company's financial statement is getting higher and public accountants are expected to fulfill one of its duties which is provide audited reports of a financial statements published by the company. The published financial statements will not only be used by the publishing company's management but also will be used by all users both internal and external users. The management team of the company is responsible to the published financial statement while the public accountant (auditor) is responsible for the audit opinion from the conducted audit process. This audit opinion will be used by all financial statement users such as investors and other companies to believe that the published financial statement is presented correctly and provides the real condition of the company. The audit opinion will also be used as an input and comparison by the investors to invest their capitals to the company. External parties from the company will also need to use the information provided by financial statements for their decision making process related to the company. External parties generally conclude their decisions based on the information provided by the management in the financial statement. Therefore, two different sides in the described situation. In one side, the company's management wanted to provide information related to their responsibilities in managing the capitals from their investor while also attracting more investors while the external parties need to get reliable information from the company. Both the management and the external parties will need an independent party to ensure the reliability of the provided financial statements. Should there be no independent party providing their opinion on the financial statements, the management will not be able to ensure the external parties and in the other hand the external parties will question about the 
reliability of the financial statements due to the underlying motivation of the company publishing the financial statement.

In the current business environment with increasing competition and global changes, accountant will face more difficult challenges in both present and the future. Many auditors are sued or if it no legal action was taken, some of the society thinks that auditor work is irrelevant and cannot be expected to be helpful. Cases have been found abroad and in the current time, the existence of such case in Indonesia is growing. On the other end, many cases still need the service of public accountants. This shows that auditors are still recognized and needed. Epstein and Geiger (1994) in their research stated that investors and financial statement users recognize benefit of auditing in financial reporting process.

The stated condition is the expectation gap phenomenon which is the difference in expectation between the users and the auditor related to the roles and responsibilities of auditors (Humphrey, 1993). Roles and responsibilities of auditor have been managed in the Public Accountant Professional Standard (SPAP) which governed by Indonesian Board of Accountant (IAI) or Statement on Auditing Standards (SAS) published by Auditing Standards Board (ASB). The enforcement of the standards in many occasions is the cause of expectation gap emergence.

\section{THEORY AND HYPOTHESES DEVELOPMENT}

Perception is the process in which an individual chooses, organizes, and interpret the information inputs to create a meaning from the world (Kotler, 2006:193). Perception is a process in which someone chooses, organizes, and interpret using their senses to get a grasp of understanding what happens around that individual (Baron \& Greenberg in Kustono, 2001).

Expectation is an observation on time variation and development of scientific development in various disciplines (Wahba and House, 1974). Related to expectation, an individual's behavior represents a conscious decision based on $\mathrm{n}$ comparison evaluation about different behavior alternatives and everyone will chose one behavior alternatives which for every alternative will results in favorable consequences (Wexley and Yukl, 1977). Gap exists due to the difference between perception and reality. One individual's expectation will be different from another individual's reality. This thing will happen in every aspect. Problem occurs when those expectations collides with the reality. According to Guy and Sullivan (1988) expectation gap is the difference between what the society and financial statement users believe or hope from the auditors and what the auditors believe as their responsibility.

Assurance services are independent professional service which increases the information quality for the decision makers (Boynton, Johnson, and Kell, 2006). Decision makers needed reliable and relevant information as the base for decision making. These services are provided by public accountant in form of attestation services.

Indrarto (2009) reveals expectation gap exists between the auditor and the financial statement users regarding the auditor issues and audit process. Auditor has more positive perception regarding the auditor issues and audit process compared to the government audited financial statement users which are caused by education and experience. The education of the auditor, both formal and informal, enhances the correct knowledge of the role and responsibilities of auditor in auditing. Other than that, the experience possessed by the auditor also increases auditing abilities so the auditor will have a full understanding of their roles and responsibilities. The financial statement users in the other hand have negative perception on roles and responsibilities auditor due to the limited knowledge and not having full understanding of the audit process, shown by taking auditing and accounting is one, not separate process. Based on the description above, we propose the following hypothesis:

$\mathrm{H} 1$ : Expectation gap exists between financial statement users and auditor in auditing process and the auditor itself.

Indrarto (2009) reveals expectation gap exists between the auditor and the financial statement users regarding the auditor issues and audit process. Auditor has more positive perception regarding the auditor issues and audit process compared to the government 
audited financial statement users which are caused by education and experience. The education of the auditor, both formal and informal, enhances the correct knowledge of the role and responsibilities of auditor in auditing. Other than that, the experience possessed by the auditor also increases auditing abilities so the auditor will have a full understanding of their roles and responsibilities. The financial statement users in the other hand have negative perception on roles and responsibilities auditor due to the limited knowledge and not having full understanding of the audit process, shown by taking auditing and accounting is one, not separate process. Based on the description above, we propose the following hypothesis:

$\mathrm{H} 2$ : Expectation gap exists between financial statement users and auditor in auditor's role.

\section{METHODS OF RESEARCH}

Population in this research is financial statement users, auditors in Surabaya and this population is considered as infinite. Meanings are a population with unknown number. In determining the sample researchers use purposive sampling techniques. Purposive sampling technique according to Sugiyono (2009:300) is a sampling technique by using certain criteria. The confidence level is $95 \%$. The sampling criteria set in this research are:

- Financial statement users consists of corporate accountant (CA), investment analysts $(\mathrm{IA})$, bankers $(B)$, and tax people $(T)$ in Surabaya;

- Auditors (A) which conducts their activities in Surabaya based Accounting Firms.

Formula for infinite sample (Zainudin,2000):

$$
n=\frac{\left(Z^{1 / 2} \alpha\right)^{2} \cdot p \cdot q}{d^{2}}=\frac{(1,96)^{2} \cdot 0,5 \cdot 0,5}{(o, 10)^{2}}=96 \approx 100
$$

Where: $\mathrm{n}=$ number of samples; $\mathrm{p}=$ estimator; $\mathrm{q}=1-\mathrm{P} ; \mathrm{Z} \alpha^{2}=$ normal curve with $\alpha=0,05$; $d^{2}=$ normal curve on 0,1 .

In this research the number of sample is 100 for every variables and variable 1 is divided into four groups. The number of samples for each group is 25 while variable 2 also consists of 100 samples to balance the number of samples for variable 1 and variable 2.

The data used in this research is qualitative data. Qualitative data is a data which could not be measured in numeric scale (Kuncoro, 2003). But due to in statistic form, all data have to be able to be measured in form of number, the qualitative data in this research is quantified for further processing by classifying in categories. Based on the sources, the used data in this research is primary data. The primary data in this research is respondent's answers to questionnaire sent by the researcher.

Based on the identification of the variables previously performed, the operational definitions of the variables are:

Expectation gap on auditor issues and audit process is the different perception between the financial statement users and auditor in the evidence gathering and evaluation process of the measureable information related to an economic entity by the auditor to be able to determine and reports the compatibility of the information with the set criteria. This variables is measured by using thirteen questions, the questions are the instrument of the previous research. Answer from the respondents is measured by using seven points likert scale. There are seven available answers for the respondents which are: "Strongly Disagree", "Disagree", "Somewhat Disagree", "Neutral", "Somewhat Agree", "Agree", and "Strongly Agree". The indicators of auditor issues and audit process (Humphrey, 1993) are:

- Audit quality have improved in the last previous years;

- Investors expects too much from the auditors;

- Auditors focuses on fulfilling the company's management demands;

- Audit process is weakened by inappropriate accounting standards;

- Auditor is willing to settle the legal actions for their negligence outside the court;

- Audit provides little benefit to the audited company; 
- The completion of an audit need a long time;

- Auditor did not understand the business problems of the auditee;

- Audit provides significant protection to frauds;

- Auditor reports the efficiency of company's management to shareholders;

- Auditors identifies the needed means to increase the company's management efficiency;

- Audit committee consists of non-executive directors increases auditors independency;

- Audit work quality have been set by the accountant profession.

Expectation gap on auditor's role is the different perception between the financial statement users and auditor in the tasks or services provide by the auditor in their work. This variables is measured by using ten questions, the questions are the instrument of the previous research. Answers from the respondents are measured by using seven points likert scale. There are seven available answers for the respondents which are: "Strongly Disagree", "Disagree", "Somewhat Disagree", "Neutral", "Somewhat Agree", "Agree", and "Strongly Agree". The indicators of auditor issues and audit process (Humphrey, 1993) are:

- In line with company's rules;

- In line with financial accounting standards;

- Consistent with the current accounting practices;

- No material deviations;

- No material misstatements;

- All material wrong doings can be detected;

- The internal control process of the auditee is satisfying;

- Company's going concern is undoubtable;

- The company is running efficiently;

- All wrongdoings have been confirmed significantly to the correct entities.

\section{RESULTS AND DISCUSSION}

Validity test is used to measure the validity of a questionnaire. Questionnaire is considered to be valid if the questions in the questionnaire can reveal something to be aware of.

Table 1 - Respondents Characteristics

\begin{tabular}{|c|c|c|c|c|c|c|c|c|c|c|}
\hline Remarks & $\mathrm{CA}$ & $\%$ & $\mathrm{~B}$ & $\%$ & $\mathrm{~T}$ & $\%$ & IA & $\%$ & $\mathrm{~A}$ & $\%$ \\
\hline $\begin{array}{l}\text { Length of service } \\
<1 \text { Year } \\
1-5 \text { Years } \\
5-10 \text { Years } \\
>10 \text { Years }\end{array}$ & $\begin{array}{l}1 \\
16 \\
5 \\
3 \\
\end{array}$ & $\begin{array}{l}4 \% \\
64 \% \\
20 \% \\
12 \% \\
\end{array}$ & $\begin{array}{l}3 \\
17 \\
5\end{array}$ & $\begin{array}{l}12 \% \\
68 \% \\
20 \%\end{array}$ & $\begin{array}{l}1 \\
4 \\
7 \\
13 \\
\end{array}$ & $\begin{array}{l}4 \% \\
16 \% \\
28 \% \\
52 \% \\
\end{array}$ & $\begin{array}{l}2 \\
21 \\
2\end{array}$ & $\begin{array}{l}8 \% \\
84 \% \\
8 \%\end{array}$ & $\begin{array}{l}41 \\
47 \\
11 \\
1 \\
\end{array}$ & $\begin{array}{l}41 \% \\
47 \% \\
11 \% \\
1 \% \\
\end{array}$ \\
\hline Total & 25 & $100 \%$ & 25 & $100 \%$ & 25 & $100 \%$ & 25 & $100 \%$ & 100 & $100 \%$ \\
\hline $\begin{array}{l}\text { Education Level: } \\
\text { Diploma } \\
\text { Bachelor Degree } \\
\text { Master Degree } \\
\text { Doctoral Degree }\end{array}$ & $\begin{array}{l}23 \\
2\end{array}$ & $\begin{array}{l}92 \% \\
8 \%\end{array}$ & $\begin{array}{l}2 \\
23\end{array}$ & $\begin{array}{l}8 \% \\
92 \%\end{array}$ & $\begin{array}{l}3 \\
19 \\
3\end{array}$ & $\begin{array}{l}12 \% \\
76 \% \\
12 \%\end{array}$ & $\begin{array}{l}1 \\
22 \\
2\end{array}$ & $\begin{array}{l}4 \% \\
88 \% \\
8 \%\end{array}$ & $\begin{array}{l}12 \\
79 \\
9\end{array}$ & $\begin{array}{l}12 \% \\
79 \% \\
9 \%\end{array}$ \\
\hline Total & 25 & $100 \%$ & 25 & $100 \%$ & 25 & $100 \%$ & 25 & $100 \%$ & 100 & $100 \%$ \\
\hline $\begin{array}{l}\text { Sex: } \\
\text { Male } \\
\text { Female }\end{array}$ & $\begin{array}{l}10 \\
15\end{array}$ & $\begin{array}{l}40 \% \\
60 \%\end{array}$ & $\begin{array}{l}7 \\
18\end{array}$ & $\begin{array}{l}28 \% \\
72 \%\end{array}$ & $\begin{array}{l}16 \\
9\end{array}$ & $\begin{array}{l}64 \% \\
36 \%\end{array}$ & $\begin{array}{l}17 \\
8\end{array}$ & $\begin{array}{l}68 \% \\
32 \%\end{array}$ & $\begin{array}{l}33 \\
67\end{array}$ & $\begin{array}{l}33 \% \\
67 \%\end{array}$ \\
\hline Total & 25 & $100 \%$ & 25 & $100 \%$ & 25 & $100 \%$ & 25 & $100 \%$ & 100 & $100 \%$ \\
\hline $\begin{array}{l}\text { Age: } \\
<25 \\
25-35 \\
36-45 \\
46-55 \\
>55\end{array}$ & $\begin{array}{l}1 \\
19 \\
2 \\
3\end{array}$ & $\begin{array}{l}4 \% \\
76 \% \\
8 \% \\
12 \%\end{array}$ & $\begin{array}{l}9 \\
16\end{array}$ & $\begin{array}{l}36 \% \\
64 \%\end{array}$ & $\begin{array}{l}15 \\
6 \\
4\end{array}$ & $\begin{array}{l}60 \% \\
24 \% \\
16 \%\end{array}$ & $\begin{array}{l}2 \\
17 \\
6\end{array}$ & $\begin{array}{l}8 \% \\
68 \% \\
24 \%\end{array}$ & $\begin{array}{l}47 \\
51 \\
2\end{array}$ & $\begin{array}{l}47 \% \\
51 \% \\
2 \%\end{array}$ \\
\hline Total & 25 & $100 \%$ & 25 & $100 \%$ & 25 & $100 \%$ & 25 & $100 \%$ & 100 & $100 \%$ \\
\hline
\end{tabular}

Source: Processed Primary Data. 
Table 2 - Validity Test

\begin{tabular}{|c|c|c|}
\hline Validity Test & Results & Notes \\
\hline $\begin{array}{c}\text { Auditors, audit process, and } \\
\text { auditor role variables }\end{array}$ & $\begin{array}{c}\text { Corrected item - Questions Total Correlation - } \\
\text { All questions are scored more than 0,138. }\end{array}$ & $\begin{array}{c}\text { All questions is valid except } \\
\text { for variable 1 P1,P2,P13 }\end{array}$ \\
\hline
\end{tabular}

Reliability test is used to find out is the conducted tests is reliable. In this research the questionnaire reliability is measured by the reliability test. A questionnaire is considered reliable if an individual in the questionnaire is consistent from time to time.

Table 3 - Reliability Test

\begin{tabular}{|c|c|c|}
\hline Validity Test & Results & Notes \\
\hline $\begin{array}{c}\text { Auditors, audit process, and } \\
\text { auditor role variables }\end{array}$ & $\begin{array}{c}\text { Questions Croncbachs Alpha -All } \\
\text { questions are scored more than }\end{array}$ & $\begin{array}{c}\text { All questions is the } \\
\text { questionnaire is reliable. }\end{array}$ \\
\hline
\end{tabular}

Table 4 - F Anova Test Results

\begin{tabular}{|c|c|c|c|c|c|c|c|}
\hline \multirow{2}{*}{ Hypothesis } & \multirow{2}{*}{ Variable } & \multirow{2}{*}{ Respondent } & \multirow{2}{*}{$\mathrm{N}$} & \multirow{2}{*}{ Mean } & \multicolumn{2}{|c|}{ Anova } & \multirow{2}{*}{ Result } \\
\hline & & & & & $F$ & Sig & \\
\hline \multirow{5}{*}{$\mathrm{H} 1$} & \multirow{5}{*}{ Auditor and Audit Process } & Auditor & 100 & 3,474 & \multirow{5}{*}{30,337} & \multirow{5}{*}{0,000} & \multirow{5}{*}{ H1 accepted } \\
\hline & & Taxation & 25 & 4,396 & & & \\
\hline & & Corporate Accountant & 25 & 4,692 & & & \\
\hline & & Banker & 25 & 4,504 & & & \\
\hline & & Investment Analysts & 25 & 4,304 & & & \\
\hline \multirow{5}{*}{$\mathrm{H} 2$} & \multirow{5}{*}{ Auditor Role } & Auditor & 100 & 4,954 & \multirow{5}{*}{12,942} & \multirow{5}{*}{0,000} & \multirow{5}{*}{ H2 accepted } \\
\hline & & Taxation & 25 & 4,568 & & & \\
\hline & & Corporate Accountant & 25 & 5,4 & & & \\
\hline & & Banker & 25 & 5,916 & & & \\
\hline & & Investment Analysts & 25 & 5,788 & & & \\
\hline
\end{tabular}

Due to ANOVA Test shows the existence of statistically significant expectation gap, the follow up test Tukey HSD is conducted. Tukey HSD is the follow up test to determine the existence of difference between every individual for the Gasperz treatment.

Table 5 - Comparative test between auditor variable and audit process subject

\begin{tabular}{|c|c|c|c|c|c|}
\hline Subject & Auditor & Tax people & Corporate accountant & Banker & Investment analysts \\
\hline Auditor & - & $0,000^{*}$ & $0,000^{*}$ & $0,000^{*}$ & $0,000^{*}$ \\
\hline Tax people & $0,000^{*}$ & - & 0,501 & 0,977 & 0,977 \\
\hline Corporate accountant & $0,000^{*}$ & 0,501 & - & 0,848 & 0,227 \\
\hline Banker & $0,000^{*}$ & 0,977 & 0,848 & - & 0,817 \\
\hline Investment analysts & $0,000^{*}$ & 0,988 & 0,227 & 0,817 & - \\
\hline
\end{tabular}

*Significant on 0,05.

Table 6 - Comparative test for auditor role subject

\begin{tabular}{|c|c|c|c|c|c|}
\hline Subject & Auditor & Tax people & Corporate accountant & Banker & Investment analysts \\
\hline Auditor & - & 0,269 & 0,145 & $0,000^{*}$ & $0,000^{*}$ \\
\hline Tax people & 0,269 & - & 0,007 & 0,000 & 0,000 \\
\hline Corporate accountant & 0,145 & 0,007 & - & 0,217 & 0,505 \\
\hline Banker & $0,000^{*}$ & 0,000 & 0,217 & - & 0,985 \\
\hline Investment analysts & $0,000^{*}$ & 0,000 & 0,505 & 0,985 & - \\
\hline
\end{tabular}

*Significant on 0,05. 
Expectation gap on auditor issues and audit process is the different perception between the financial statement users and auditor in the evidence gathering and evaluation process of the measureable information related to an economic entity by the auditor to be able to determine and reports the compatibility of the information with the set criteria.

The results of the hypothesis test shows that the first hypothesis is accepted. This is shown statistically that the significance of the ANOVA F Test is 0,000 lower than $a=0,05$. This indicates that expectation gap between the auditor, tax people, corporate accountant, banker and investment analyst in the auditor and audit process issues.

One of the cause for the different perception regarding the auditor and audit process between auditor, tax people, corporate accountant, banker and investment analyst in the auditor and audit process issues is caused by education and experience. Auditor have the perception that auditor can only provide reasonable assurance while the financial statement perception is auditor should be able to provide absolute assurance. Reasonable assurance is the degree of confidence to certain limits provided by the auditor due to the time and cost restraints. Reasonable assurance is achievable by using the materiality level in the audit process, which is the filtering for the values which will be ensured for its fairness. Reasonable assurance will results in audit which detects material misstatements while absolute assurance is a definite guarantee that even immaterial misstatement does not exist in the financial statements. This level of assurance can be given only if the auditor does not have any costs or time constraint. Due to the constraints in costs and time, auditor can only provide $60 \%$ assurance instead of $100 \%$ which is based on the AICPA Audit guide which states that the number of correct stated number is $60 \%$ of the transaction above the materiality with the number of minimum transaction is 250 .

This hypothesis test supports previous research conducted by Dudy S. Ramdhany (2012) in Semarang, which shows that expectation gap exists between the financial statement user group and the auditor group in the auditor and audit process issues. Indrato (2008) in his research also shows the same result, expectation gap exists between the auditor and financial statement users in auditor and audit process issues.

Expectation gap in auditor role is the different perception between the financial statement user and auditor in the roles or services provided by the auditor in their respected departments. Roles of auditor according to Prihanto (2000) covers: Business assurance (Audit and Review), Consulting, Financial Advisory Service (financial Forecast and Projections, Merger and Acquisition), Human Resources Advisory (Other Employee Benefit, Recruitment), Others (International Services, Litigation Service).

The result of the hypothesis test shows that the second hypothesis is accepted. This is shown statistically that the $F$ Anova test significance is 0,000 which is lower than $a=0,05$. This indicates that expectation gap exists between the auditor, tax people, corporate accountant, banker and investment analyst in the auditor role issues.

One of the causes for the different perception regarding the auditor and audit process between auditor, tax people, corporate accountant, banker and investment analyst in the auditor and audit process issues is caused by education and experience. This shows the existence of expectation gap, stated by Guy and Sullivan (1988) the expectation gap exists due to the difference of what the society and financial statement user believe as auditor's responsibility and what the auditors believe as their responsibilities. The expectation of the financial statement user and society to auditors about financial statements exceeds the auditor role and their audit opinion.

Due to the rules set and known by the auditor, auditor thinks that their role is providing Business assurance (Audit and Review), Consulting, Financial Advisory Service (financial Forecast and Projections, Merger and Acquisition), Human Resources Advisory (Other Employee Benefit, Recruitment), or other services (International Services, Litigation Service) while the financial statement users based on Porter (2008) is to detect thefts and misuse of company assets. The financial statement users perceive that the misuse of company assets, even the smallest scale, will be detected by the auditor this also includes detecting the deviated accounting procedure for the financial statement and detecting errors in the financial statements for all transactions. It is already stated in the auditor and audit process 
expectation gap that auditors conduct their process based on the materiality concept. Detecting and reporting illegal actions by the employees is also expected to be done by the auditor while the rule states that the auditor's role is only related to illegal actions by the directors/managements which directly affects the company's financial statement such as doing bribery. Society also thinks that auditor's role is also related to non-financial information such as the company's internal control, checking the effectivity and efficiency of the company's management, and evaluating the impact of the company's operation to the environment.

This hypothesis test supports the previous research done by Dudy S. Ramdhany (2012) in Semarang, which shows that expectation gap exists between the financial statement user group and the auditor group regarding the auditor's role. Indrato (2008) in his research also shows the same result, expectation gap exists between the auditor, financial statement users, accountant lecturers, and accounting students regarding the auditor's role.

\section{CONCLUSION}

Based on the research objective, hypothesis, and the conceptual framework, the conclusion of the research is as follows:

The first hypothesis is accepted, which is the statistically significant existence of expectation gap between the users of financial statement and auditor in the auditor and audit process issues. This is caused by the difference in education and experience factors between the auditors and financial statement users. Auditors perceive that auditor can only provide reasonable assurance, not absolute assurance as expected by the financial statement users.

The second hypothesis is accepted, which is the statistically significant existence of expectation gap between the users of financial statement and auditor related to auditor's role. This is caused by the difference in education and experience factors between the auditors and financial statement users. Auditor's role according to auditors is providing Business assurance (Audit and Review), Consulting, Financial Advisory Service (financial Forecast and Projections, Merger and Acquisition), Human Resources Advisory (Other Employee Benefit, Recruitment), or other services (International Services, Litigation Service) while the expectation of financial statement users are beyond those scopes.

\section{REFERENCES}

1. Anshori, Muslich dan Sri Iswati. 2006. Metode Penelitian Kuantitantif. Surabaya: Fakultas Ekonomi Universitas Airlangga.

2. Arens, Alvin A. dan James K. Loebbecke. 2006. Auditing An Integrated Approach. Eighth Edition. New York: Prentice Hall International, Inc.

3. Badudu-Zain. 1994. Kamus Umum Bahasa Indonesia. Jakarta: Pustaka Sinar Harapan.

4. Boynton, William C.,Raymond N. Johnson. 2006. Modern Auditing. Eight

5. Edition. New Jersey: John Wiley \& Sons, Inc.

6. Christiawan, J.J. 2002. "Kompetensi dan Independensi Akuntan Publik: Refleksi hasil penelitian Empiris". Jurnal Akuntansi dan Keuangan Vol. 4. No.2 Nov 2002.

7. DeZoort \& Barney. 1991. A Public Accounting Career: The Gap between Student Expectation and Accounting Staff Experiences. Accounting Horizons. pp.7-12

8. Erlina. (1993). Persepsi Akuntan Publik dan Pemakai Laporan Pemeriksaan terhadap Laporan di Pasar Modal Indonesia. Tesis S- 2 UGMYogyakarta.

9. Ermawan, D. 2001. "Analisis Persepsi Pemakai Informasi Akuntansi, Akuntan Bukan Akuntan Publik, Masyarakat Umum, dan Akuntan Publik terhadap Tugas Akuntan Publik". Tesis. Semarang: Program Pascasarjana Fakultas Ekonomi Undip

10. Gaspersz, Vincent. (1992). Teknik Analisis dalam Penelitian Percobaan. Tarsito, Bandung.

11. Gramling, A \& Wallace. 1996. "The Role of Undergraduated Auditing Coursework in Reducing the Expectation gap". Accounting Education, Vol. 11 (1): 131-160 
12. Guy. Dan. M \& Jerry. D. Sullivan. (1988). "The Expectation gap Auditing Standar". Journal of Accountancy (April): 36-46.

13. Humprey. 1993. "The Audit Expectation gap in Britain: An Empirical Investigation". Accounting \& Business Research Vol.23 (91A). pp. 395- 411.

14. Husein Umar, 2003, Metodologi Penelitian Untuk Skripsi dan Tesis Bisnis,Jakarta: PT. Gramedia Pustaka.

15. Ikatan Akuntan Indonesia. (2001). Standar Profesional Akuntan Publik, per 1 Januari 2001. Jakarta: Penerbit Salemba Empat.

16. Indrarto, M 2009. "Persepsi Pemakai Laporan, Auditor, Akuntan Pendidik, dan Mahasiswa Akuntansi terhadap Expectation gap (Dalam Isu Auditor \& Proses Audit, Peran Auditor, serta Kompetensi dan Independensi Auditor)". Jurnal Ekonomi Akuntansi.

17. Kuncoro, Mudrajad. 2003. Metode Riset untuk Bisnis dan Ekonomi. Jakarta: Erlanga.

18. Kustono, A. S. 2001. "Persepsi Dosen Akuntansi terhadap Kesetaraan PABU dan SAK". Makalah Simposium Nasional Akuntansi IV.

19. Malhotra, Naresh. 1996. Marketing Research and Applied Orientation. New Jersey: Prentice Hall.

20. Mulyadi. 2002. Auditing. Buku Satu. Edisi Kelima. Jakarta: Salemba.

21. Mayangsari, S. 2003. "Pengaruh Keahlian Audit dan Independensi terhadap Pendapat Audit: Sebuah Kuasi Eksperimen". Makalah Simposium Nasional Akuntansi 3, Jakarta, 5 September 2000.

22. Nazir, Moh. 2005. Metode Penelitian. Jakarta: Ghalia Indonesia.

23. Porter, B. 1993. "An Empirical Study of The Audit Expectation gap-Performance Gap". Accounting Business Research, Vol. 24 (93): 49-68

24. Prihanto, G. 2000. "Perbedaan Persepsi Antara Manajer dan Mahasiswa Akuntansi terhadap Profesi Akuntan Publik di Indonesia". Skripsi (Tidak Diterbitkan). Surakarta: FE UNS.

25. Scott W.R 2003 Financial Accounting Theory, edisi Ketiga, Prentice-Hall Canada.Inc Scarborough, Ontario.

26. Soedjais, Z. 1999. Peran Profesi Akuntan dalam Upaya Pemberdayaan Ekonomi Kerakyatan di Era Reformasi. Jakarta: Himaka Universitas Pancasila.

27. Suatmaja, Y. 2004. "Persepsi Pemakai Laporan Keuangan, Auditor, dan Mahasiswa Akuntansi terhadap Expectation gap dalam Isu Peran Auditor dan Aturan, serta Larangan pada Kantor Akuntan Publik". Skripsi (Tidak Diterbitkan). Surakarta: Fakultas Ekonomi Universitas Sebelas Maret.

28. SPAP - Standar Profesional Akuntan Publik. 2011. Standar Auditing. Seksi: 105. Jakarta: Salemba Empat.

29. Sugiyono. 2009. Metode Penelitian Bisnis. Bandung; Alfabeta

30. Wahba, M.A., dan House, R.J. 1974. "Expectancy Theory In Work and Motivation: Some Logical and Methodological Issues". Human Relations.Vol. 27, No. 1:121-147.

31. Wexley, Kenneth N, dan Yukl, Gary A. 1977. Employee Motivation to Work, Organizational Behaviour and Personnel Psychology. Richard D. Irwin Inc., Homewood, Illionis

32. Winarna, J. \& Suparno, Y. 2003. "Peran Pengajaran Auditing terhadap Pengurangan Expectation gap". Jurnal Bisnis dan Manajemen. 